\title{
First record of Kentrocapros rosapinto (Tetraodontiformes: Ostraciidae) from Vema Seamount (south-east Atlantic)
}

\author{
A. Armesto*, R. Bañón* ${ }^{\ddagger}$, D. Garabana* and P. Durán ${ }^{\dagger}$ \\ *Asociación Científica de Biología Marina 'Augamar', Avda. Fragoso 93 - $5^{\circ}$ Izda., 36210 Vigo, Spain. \\ ${ }^{\dagger}$ Instituto Español de Oceanografía, Aptdo. 1552, 36208 Vigo, Spain. \\ ${ }^{\ddagger}$ Corresponding author, e-mail: rbanon@jazzfree.com
}

The capture of a specimen of Kentrocapros rosapinto at Vema Seamount in the south-east Atlantic Ocean is reported as the first record of this species in the Atlantic Ocean. This species was previously known only from the western Indian Ocean.

Fish of the genus Kentrocapros Kaupp, 1855 are marine fish from benthic tropical and subtropical waters from the south-western Indian Ocean (Winterbottom \& Tyler, 1983). The genus Kentrocapros Kaupp, 1855 comprises three or four valid species Kentrocapros aculeatus (Houttuyn, 1792) from Japan and China, (with the type species, Ostracion hexagonus Thunberg 1787 as a junior synonym); Kentrocapros flavofaciatus (Kamoara, 1938) from Japan and China; Kentrocapros eco (Phillips, 1932) from New Zealand and Kentrocapros rosapinto (Smith, 1949) from the western Indian Ocean.

The Vema Seamount is situated in the South Atlantic (Figure 1), near the centre of the Cape Basin, approximately midway between the Walvis Ridge and the South African mainland.
One specimen of $K$. rosapinto was collected during the exploratory fishery survey VAL 97, carried out by a Spanish commercial bottom trawler in 1997 in the south-eastern Atlantic. Afterwards the specimen was preserved in $70 \%$ ethanol and stored in the fish collection of the Instituto Español de Oceanografía in Vigo (IEOV). Methods for measurements and counts followed Matsuura \& Yamakawa (1982).

$$
\text { Kentrocapros rosapinto (Smith, 1949) }
$$

\section{Material examined}

IEOV 01897 (Figure 2), $107 \mathrm{~mm}$ SL, Vema Seamount, 31 ${ }^{\circ} 41^{\prime} \mathrm{S}-$ $08^{\circ} 22^{\prime} \mathrm{E}$, depth unknown, 19 September 1997.

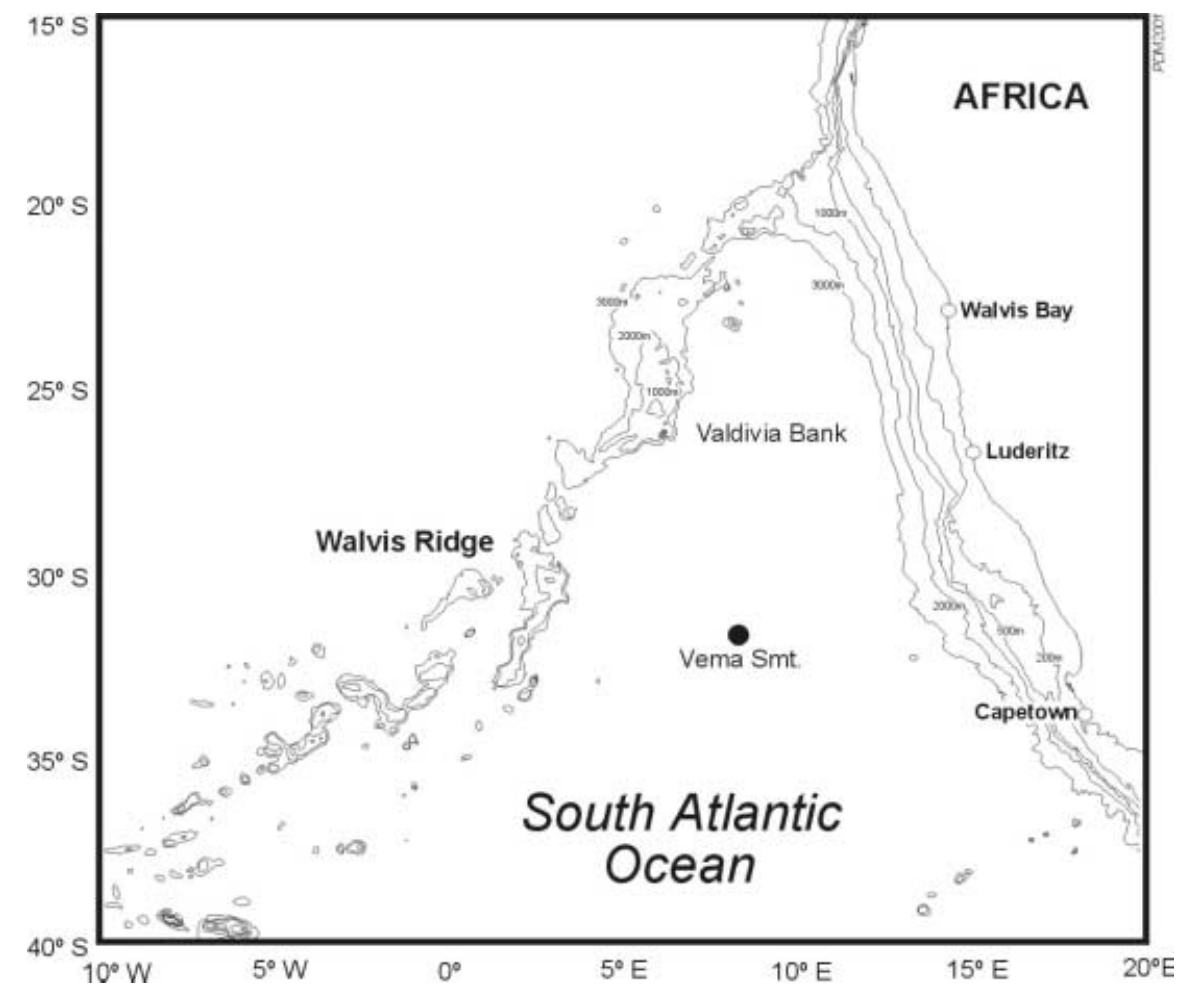

Figure 1. South-east Atlantic Ocean, showing Vema Seamount where Kentrocapros rosapinto was captured. 


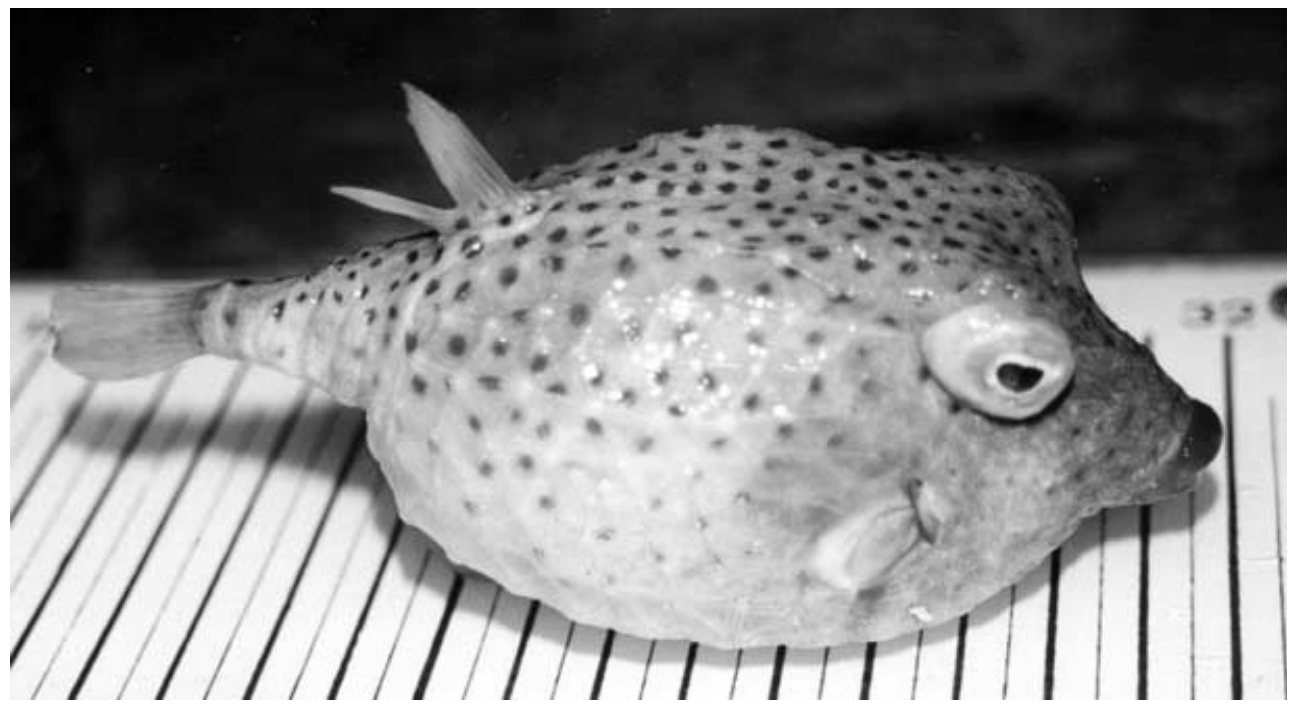

Figure 2. Kentrocapros rosapinto, $107 \mathrm{~mm}$ standard length from Vema Seamount.

\section{Diagnosis}

Dorsal fin rays: 11; anal fin rays: 10; pectoral fin rays: 11; caudal fin rays: 11. The following measurements are shown in millimetres followed by the percentage in standard length in parentheses. Total length, 131; standard length, 107; head length, 34 (31.8); snout length, 24 (22.4); eye diameter, 15 (14); interorbital width, 15 (14); postorbital length, 10 (9.3); gill opening length, 7 (6.5); predorsal length, 77 (72); dorsal fin height, 19 (17.7); length of dorsal fin base, 10 (9.3); preanal length, 81 (75.7); anal fin height, 17 (15.9); length of anal fin base, 9 (8.4); pectoral fin length, 20 (18.7); caudal fin length, 23 (21.5); caudal peduncle depth, 8 (7.5); tail length, 24 (22.4); tail depth, 26 (24.3); body width, 29 (27.1); body depth, 47 (43.9).

Body enclosed in a rigid carapace with six ridges without spines. This carapace is constituted by plates, most of them hexagonal; eye large, two nostrils in front of eye; mouth small and inferior; lips fleshy; small incisiform teeth in a single row in each jaw; gill opening small, almost vertical situated below posterior edge of the orbit.

The fresh fish was yellowish in body with numerous dark greenish brown spots on the dorsolateral part of the head and body, decreasing in number ventrally; lips dark red and fins yellow. According to Matsuura \& Yamakawa (1982), this coloration corresponds with the description of a female.

\section{Distribution}

Mascarene Ridge between Seychelles (Matsuura \& Yamakawa, 1982), Maputo Bay and southern Mozambique (P.C. Heemstra, personal communication), Walters Shoal south of Madagascar (Collete \& Parin, 1991) and the Maldive Islands (Manilo, 1993).

Kentrocapros rosapinto is one of the least known and rare boxfishes. This species is very similar to $K$. flavofasciatus Kaup, 1855, known from the Pacific coasts of China and Japan and in New Caledonia. The difference between them is the position of the gill opening, slightly oblique and located below the posterior half of the eye in $K$. flavofasciatus while $K$. rosapinto has the gill opening almost vertical or very slightly oblique and located below the posterior edge of the eye.

The presence of $K$. rosapinto, at Vema Seamount is unexpected, although the fish fauna of the Vema Seamount is poorly known and only about 31 species are known from this seamount.
Wilson \& Kaufman (1987) recognized the southern current West Wind Drift as an important means of dispersal for shallowwater marine fish in the Southern Hemisphere. The northern portion of this current is influenced by cyclonic gyres in the south-western Indian Ocean, and eddies from the south-flowing Agulhas Current may carry Indian Ocean and Indo-west Pacific species round the south coast of South Africa and into the Atlantic Ocean (Kensley, 1981). The recent discovery of the Indo-Pacific species Parapercis roseoviridis and Chrionema chlorotaenia at Vema Seamount and on the Walvis Ridge (Bañón et al., 2001) are additional examples of such transport.

This study was supported by the Instituto Español de Oceanografía (IEO).

\section{REFERENCES}

Bañón, R., Armesto, A., Garabana, D. \& Durán, P., 2001. First record of Chrionema chlorotaenia (Perciformes: Percophidae) from the southeastern Atlantic. Cybium, 25, 278-280.

Collette, B.B. \& Parin, N.V., 1991. Shallow-water fishes of Walters Shoals, Madagascar Ridge. Bulletin of Marine Science, 48, 1-22.

Kensley, B., 1981. On the zoogeography of southern African decapod crustacean, with a distributional cheklist. Smithsonian Contribution to Zoology, 338, 1-64.

Manilo, L.G., 1993. On the discovery of Kentocapros rosapinto (Ostraciontidae) off the Maldive Islands. Fournal of Ichthyology, 33, 134-135.

Matsuura, K. \& Yamakawa, T., 1982. Rare boxfishes, Kentocapros flavofasciatus and $K$. rosapinto, with notes on their relationships. Japanese Journal of Ichthyology, 29, 31-42.

Wilson, R. \& Kaufman, R., 1987. Seamount biota and geography. In Seamounts, islands and attolls (ed. B. Keating et al.), pp. 355-377. Washington: American Geophysical Union. [Geophysical Monograph, no. 43.]

Winterbottom, R. \& Tyler, J.C. 1983. Phylogenetic relationships of Aracanin genera of Boxfishes (Ostraciidae: Tetraodontiformes). Copeia, 4, 902-917. 